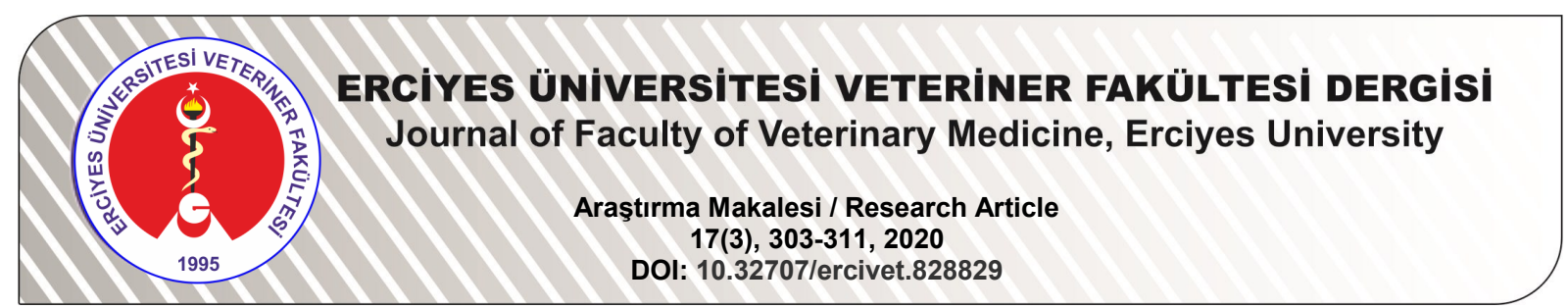

Determination of Phenotypic and Genome Characteristics of Chryseobacterium sp. C-204 Strain Isolated from Rainbow Trout

\author{
Izzet Burcin SATICIOĞLU1', Muhammed DUMAN², Soner ALTUN²
}

\author{
${ }^{1}$ Erciyes University, Faculty of Veterinary Medicine, Aquatic Animal Disease Department, Kayseri-TURKEY \\ ${ }^{2}$ Bursa Uludag University, Faculty of Veterinary Medicine, Aquatic Animal Disease Department, Bursa-TURKEY
}

Corresponding author: Izzet Burcin Saticioglu; E-mail: iburcinsat@gmail.com; ORCID: 0000-0002-2721-3204

How to cite: Saticioglu IB, Duman M, Altun S. Determination of phenotypic and genome characteristics of Chryseobacterium sp. C-204 strain isolated from rainbow trout. Erciyes Univ Vet Fak Derg 2020; 17(3): 303-311.

Summary: In recent years, species in the Chryseobacterium genus have emerged as opportunistic fish pathogens that can cause death in fish in many countries. In the last decade, $C$. aahli, $C$. oncorhynchi, C. chaponense, and C. piscicola have been reported to cause systemic infections in fish. In the present study, Chryseobacterium sp. C-204 was isolated from $1 \mathrm{~g}$ weight rainbow trout showing clinical signs such as abnormal swimming, dorsal skin ulceration, darkening in color, and bilateral exophthalmos. The detailed phenotypic characteristics of the C-204 were characterized by API 20NE, and the BIOLOG GEN III system includes 106 phenotypes. Antimicrobial susceptibility of the C-204 was also determined by the broth microdilution method against five antimicrobial agents commonly used in the Aquaculture. Sequence-based identification was done using 16S rRNA genome sequencing. The genome structure of the C-204 was revealed by using next-generation genome sequencing with reading a total of 24195304 bases and assembled in 4012452 base. Genome-based species delineation of C-204 was done 100 different housekeeping gene regions and 50 the closest Chryseobacterium species with Automated Multi-Locus Species Tree (autoMLST, https:// automlst.ziemertlab.com). Antimicrobial resistance genes (AMR) and virulence genes in the C-204 genome were identified using the Virulence Factor Database (VFDB) NCBI-reference antimicrobial resistance genes database. The 16S rRNA sequence of C-204 isolate had similarities with the C. aquaticum $(99.65 \%)$ and C. greenlandense $(98.95 \%)$ in GenBank. In parallel 19 biochemical tests, C-204 isolate can be differentiated from the closest type strains by nitrate reduction and inability to produce acid from glucose. With regard to antimicrobial susceptibility, the C-204 isolate can grow even at high antimicrobial concentrations determined for Flavobacteriaceae. According to genome-based species delineation, the C-204 isolate was identified as Chryseobacterium aquaticum subsp greenlandense. 13 virulence and eight AMR genes were detected in the genome of the C-204 isolate. Conclusively, the detailed phenotypic characteristic includes 106 biochemical test and genome structure of C-204 isolate by whole genome sequencing were determined.

Key words: Antimicrobial resistance genes, Chryseobacterium sp., virulence genes

\title{
Gökkuşağı Alabalıklarından Izole Edilen Chryseobacterium sp. C-204 Suşunun Fenotipik ve Genom
} Özelliklerinin Belirlenmesi

Özet: Son yıllarda Chryseobacterium cinsinde bulunan türler, birçok ülkede balıklarda ölümlere neden olabilen fırsatçı balık patojenleri olarak ortaya çıkmaktadır. Yalnızca son on yılda C. aahli, C. oncorhynchi, C. chaponense ve C. piscicola'nın balıklarda sistemik enfeksiyonlara neden olduğu bildirilmiştir. Bu çalışmada, Chryseobacterium sp. C-204, anormal yüzme, sırt lezyonu, renkte koyulaşma ve iki taraflı egzoftalmi gibi klinik belirtiler gösteren 1 gram ağırlığındaki gökkuşağı alabalığından izole edildi. C-204'ün 106 farklı testi içeren fenotipik özellikleri API 20NE ve BIOLOG GEN III sistemi ile karakterize edildi. C-204'ün antimikrobiyal duyarııı̆ı, su ürünleri yetiştiriciliğinde yaygın olarak kullanılan beş farklı antimikrobiyal ajana karşı broth mikrodilüsyon yöntemiyle belirlendi. Dizi analizi bazlı tür tanımlama, 27F ve 1387R primerleri kullanılarak yapıldı. C-204'ün tüm genom analizinde, yeni nesil dizilime sistemi kullanıldı ve toplam 24195304 okuma elde edildi. Bu okumalar birleştirilerek 4012452 baz uzunluğunda taslak genom elde edildi. C-204'ün genoma dayalı tür tanımlaması, 100 farklı korunmuş gen bölgesi ve en yakın 50 Chryseobacterium türü ile autoMLST sisteminde (https://automlst.ziemertlab.com) yapıldı. C-204 genomundaki antimikrobiyal direnç genleri (AMR) ve virülans genleri, NCBI referans antimikrobiyal direnç genleri veritabanı ve Virülans Faktör Veritabanı (VFDB) kullanılarak tanımlandı. C-204 izolatının 16S rRNA gen bölgesinin, GenBankta C. aquaticum ile \%99.65 ve C. greenlandense ile \%98.95 oranında benzerliklere sahip olduğu belirlenmiştir. Ortak yapılmış olan 19 biyokimyasal testte, C204 izolatı nitrat indirgeyebilmesi ve glikozdan asit üretememesi testleri ile diğer tip suşlardan ayrılabildiği belirlenmiştir. Antimikrobiyal duyarlılıkla ilgili olarak, C-204 izolatının yüksek antimikrobiyal konsantrasyonlarında bile üreyebildiği tespit edilmiştir. Genom bazlı tür tanımlamasına göre, C-204 izolatı, Chryseobacterium aquaticum subsp greenlandense olarak tanımlandı. Ayrıca, C-204 suşunun genomunda 13 virülans ve sekiz AMR geni tespit edildi. Çalışmamızda sonuç olarak, C-204 izolatının 106 biyokimyasal özellik içeren detaylı fenotipik ve tüm genom dizi analizine dayalı genom yapısı belirlenmiştir.

Anahtar kelimeler: Antimikrobiyal direnç geni, Chryseobacterium sp., virülens geni 


\section{Introduction}

In the last thirty years, aquaculture has grown rapidly in Turkey, and the total amount of products obtained from 2286 farms in 2018 reached 276502 tons, and total fisheries exports reached $\$ 952$ million (BSGM, 2020). With the rapid development of aquaculture, economic losses from diseases caused by pathogens have also increased. The family of Flavobacteriaceae has a considerable sizeable ecological habitat. The species in this family; Invertebrates, amphibians, reptiles, birds, and even human beings can cause infections in mammals. Among the species causing fish infection in the Flavobacteriaceae family, there are significant species such as Flavobacterium sp., Tenacibaculum sp., and Chryseobacterium sp. It has been reported that Chryseobacterium species are isolated from different clinical cases (pneumonia, peritonitis, surgical wound infections, burn wounds, eye infections, newborn pneumonia, etc.) in humans (Loch and Faisal, 2015a). Chryseobacterium species have been reported to cause economic losses in many fish species on different continents. Only in recent years C. piscicola, C. chaponense, C. aahli, and $C$. oncorhynchi have been reported to cause systemic infections in fish (Hugo et al., 2019).

There are not many studies on whether the detected Chryseobacterium species are the main cause of the disease. In a limited number of studies, it was reported that $C$. balustinum, C. piscicola, and $C$. aahli fulfill Koch postulates, but there is no study on other Chryseobacterium species (Ilardi et al., 2009; Loch and Faisal, 2015b, 2014).

In our study, it was aimed to determine the comprehensive phenotypic characterization, genome analysis, and antimicrobial susceptibility of $C$. aquaticum subsp. greenlandense C-204 isolate isolated from rainbow trout showing disease symptoms such as dorsal skin ulceration, darkening in color, and bilateral exophthalmia.

\section{Materials and methods}

\section{Bacterial isolate and phenotypic characterization}

In our study, the C-204 isolate was isolated from a rainbow trout, weighing about $1 \mathrm{gram}$ in the trout farm located in the Aegean region, 2015, showing signs of abnormal swimming, dorsal lesion, darkening in color, and bilateral exophthalmos was used. This research was approved by Bursa Uludag University, the Local Ethics Commission (report 2012-14/04).

In primary isolation, Tryptone Yeast Extract Salts (TYES) agar was used, and the agent was incubated at $25^{\circ} \mathrm{C}$ for 48 hours. Conventional microbiological tests such as Gram staining, motility, oxidase, presence or absence of flexirubin pigment, catalase activity were used in phenotypic characterization of strains
(Loch et al., 2013). The morphological and biochemical profiles of C-204 isolate were determined using the Biolog GEN III microplate (Biolog, Hayward, CA, USA) and API 20NE (Biomerieux, France) tests. Unlike the manufacturer's protocol, the incubation temperature and time were modified to optimum growth values of $\mathrm{C}-204$ isolate $\left(48 \mathrm{~h}\right.$ incubation at $25^{\circ} \mathrm{C}$ ).

\section{Sequence analysis based on 16S rRNA gene}

DNA extraction of C-204 isolate was performed according to the spin column filtration (QIAamp DNA Minikit; Qiagen, Hilden, Germany) method. PCR and sequence analysis was performed using 27F (5'-AGA GTT TGA TCM TGG CTC 118 AG-3') and 1387R (5'GGG CGG WGT GTA CAA GGC-3') based on the 16S rRNA gene region (Loch et al., 2013). The obtained chromatograms were aligned and identified in the BLAST (Basic Local Alignment Search Tool) server database in the National Center for Biotechnology Information (NCBI).

\section{Whole-genome sequencing}

The sequencing library was prepared using Nextera XT DNA Library Preparation Kit, and sequencing was done by Illumina NovaSeq 6000 platform as pairedend (PE) 2x150 bases reads with using a 500-cycle MiSeq reagent kit (Cooper et al., 2015). The Fastq file obtained from the sequence analysis was uploaded to Geneious Prime (version 2020.1.2). The reads with low-quality scores $(<20)$ or poly-Ns and adaptor contamination were then trimmed using BBDuk as implemented in Geneious Prime (Kearse et al., 2012). The high-quality reads of C-204 were assembled into costig by de novo assembly using SPAdes assembler 3.13.0 (Bankevich et al., 2012). The draft genome sequence has been recorded to Genbank with SAMN15009847 and PRJNA634826 BioSample and BioProject number, respectively.

\section{Genomic data analysis}

Genome-based species delineation of C-204 was created using Automated Multi-Locus Species Tree (autoMLST, https://automlst.ziemertlab.com). In phylogenetic analysis, 100 different housekeeping gene regions of C-204 and 50 the closest Chryseobacterium species genomes were used. A high-resolution species tree was created using the web-based autoMLST program (Alanjary et al., 2019). Annotation of the C-204 genome was performed using NCBIAutomatic Prokaryotic Genome Annotation Pipeline (PGAP) (Tatusova et al., 2016). Virulence genes in the C-204 genome were identified using the Virulence Factor Database (VFDB), while the antimicrobial resistance genes were identified by searching BLASTX (E-value <1e-50) in the Geneious Prime software using the NCBI-reference antimicrobial resistance genes database (Feldgarden et al., 2019; Kearse et al., 2012; Lee et al., 2019). 


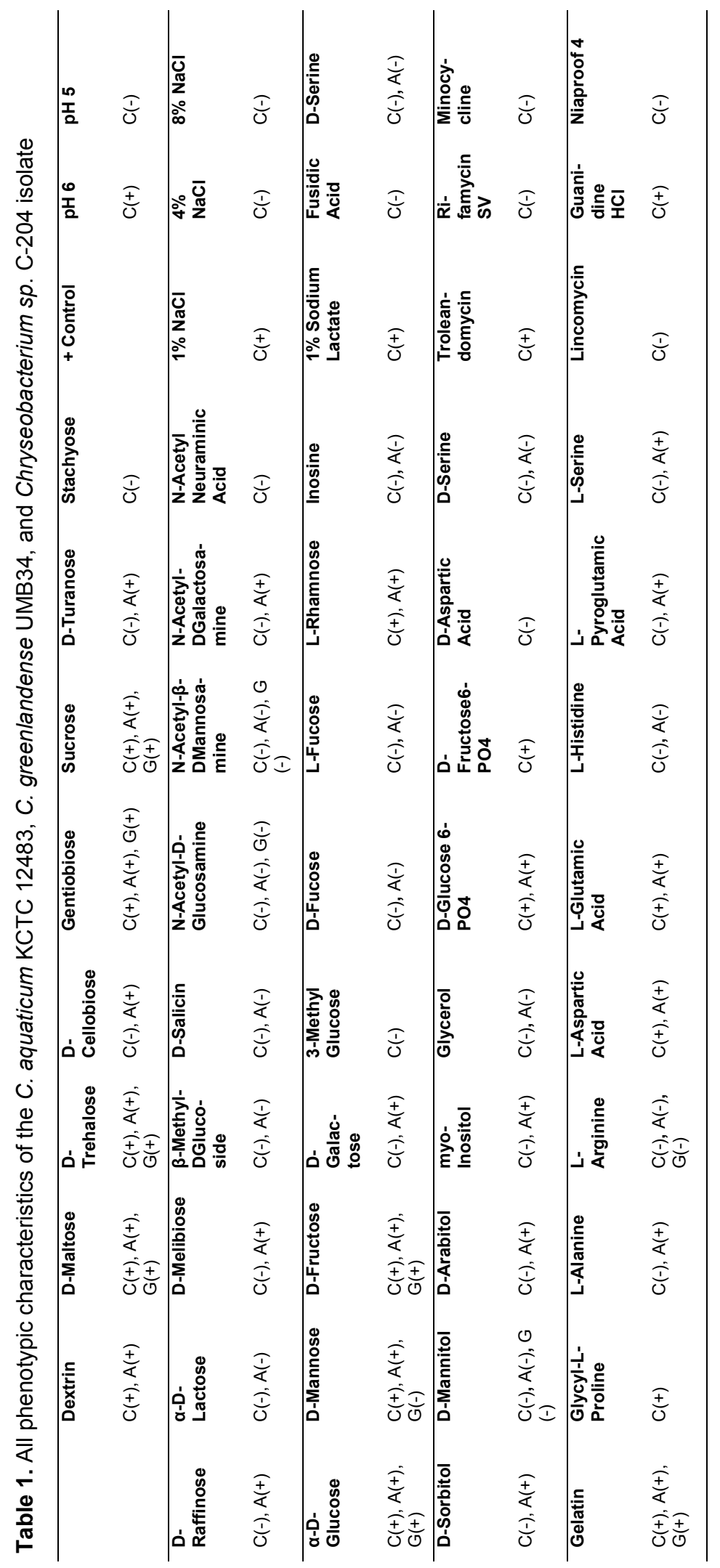




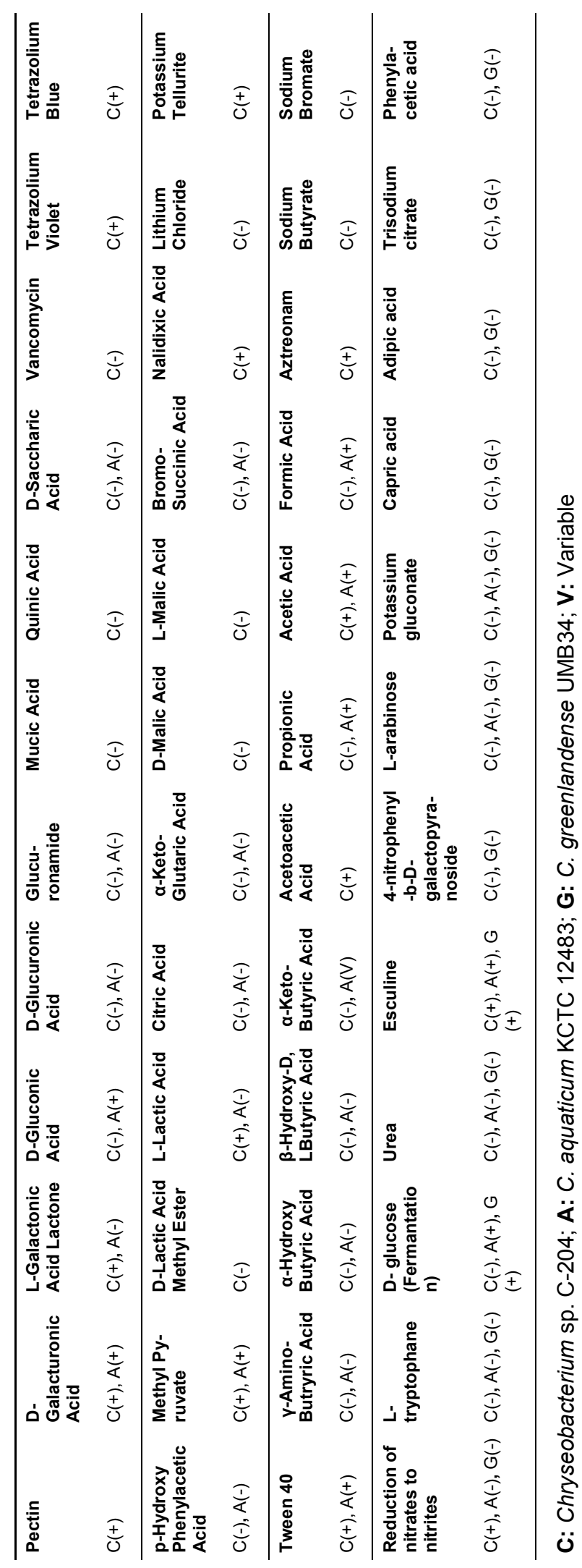




\section{Antimicrobial susceptibility testing (AST)}

Antimicrobial susceptibility level was determined by minimum inhibitory concentration (MIC) testing against Oxytetracycline (OXY), Florfenicol, (FLO), Amoxicillin (AMO), Enrofloxacin (ENR), and Sulfamethoxazole-Trimethoprim (TRS) with 0.008 and 256 $\mathrm{mg} / \mathrm{L}$ concentrations. E. coli ATCC 25922 was used as quality control (QC) strain (CLSI, 2014a, 2014b). After incubation at $22{ }^{\circ} \mathrm{C}$ for $48-72 \mathrm{~h}$, plates were measured at a wavelength of $595 \mathrm{~nm}$ in a microplate reader (Multiscan Go, Thermo), and MICs were defined as the lowest concentrations of antibiotic that inhibited growth.

\section{Results}

The C-204 isolate was isolated from the kidney in rainbow trout in the bacteriological sampling. The isolate was gram-negative, non-motile, oxidase, cata- including L-arabinose, D-mannitol, N-acetyl glucosamine, potassium gluconate, capric acid, adipic acid malic acid, trisodium citrate, or phenylacetic acid. The isolate hydrolyzed gelatin and esculin but did not hydrolyze 4-nitrophenyl-b-D-galactopyranoside (PNPG). It reduced nitrate to nitrite, but not produced indole, arginine dihydrolase. Furthermore, the production of acid from glucose was negative. All phenotypic characteristics of the closest two species and C204 isolate are presented in Table 1. It was determined that the 16S rRNA sequence of $\mathrm{C}-204$ isolate had similarities with the NCBI reference sequences in GenBank with C. aquaticum (99.65\%) and C. greenlandense (98.95\%).

MIC values of $\mathrm{C}-204$ isolate were determined for $\mathrm{FLO}=16 \mathrm{mg} / \mathrm{L}, \mathrm{OXY}=4 \mathrm{mg} / \mathrm{L}, \mathrm{AMO}=16 \mathrm{mg} / \mathrm{L}$, TRS= $4 / 76 \mathrm{mg} / \mathrm{L}$ and $\mathrm{ENR}=0.064 \mathrm{mg} / \mathrm{L}$. The $\mathrm{MIC}$ values of the QC strain (E. coli ATCC 25922) were within the

Table 2. Genomic characteristics of Chryseobacterium sp. C-204 isolate

\begin{tabular}{lc}
\hline Characteristics & C-204 \\
GeneBank ID & JABSUA000000000 \\
Genome Coverage & $394.0 X$ \\
Genome size (bp) & 4012452 \\
No. contigs & 23 \\
N50 contig size & 362647 \\
Largest contig size & 954203 \\
GC-content (\%) & 339 \\
Total genes & 3661 \\
Protein-coding genes (CDS) & 3590 \\
tRNAs & 65 \\
Pseudogenes & a \\
\hline
\end{tabular}

${ }^{a}$ The number of total Pseudogenes indicated includes genes with ambiguous residues, frameshifted gens, incomplete genes, genes with internal stopes, or other multiple problems.

lase, and flexirubin pigment positive. C-204 assimilated D-glucose, D-maltose, and D-mannose, but not the other substrates present on the API 20 NE strip, acceptable range recommended by the CLSI standards (CLSI, 2014b).

Tablo 3. Putative AMR and virulence genes annotated in C-204 genome

\begin{tabular}{|c|c|c|}
\hline \multicolumn{3}{|c|}{ Antimicrobial Resistance Gene } \\
\hline Resistance Mechanism & AMR Genes & Antimicrobial Class \\
\hline Antibiotic efflux & taeA, oqxB23, oqxB7, tet(60) & $\begin{array}{l}\text { Pleuromutilin, Tetracycline, Glycylcycline, Dia- } \\
\text { minopyrimidine, Nitrofuran, Fluoroquinolone }\end{array}$ \\
\hline Antibiotic inactivation & $b / a_{G O B-8}, b l a_{C I A-1}$ & Penam, Cephalosporin, Carbapenem \\
\hline Antibiotic target alteration & mupB & Mupirocin \\
\hline Antibiotic target protection & optrA & $\begin{array}{l}\text { Pleuromutilin, Tetracycline, Oxazolidinone, } \\
\text { Lincosamide, Streptogramin, Macrolide, Feni- } \\
\text { kol }\end{array}$ \\
\hline Virulence Genes & & Mechanism \\
\hline $\begin{array}{l}\text { eno, htpB, pgi, dnaK, icl, } \\
\text { KOX_00005, clpC, CarB, } \\
\text { Zmp1,AdeG, LigA, rpoN, } \\
\text { clpB }\end{array}$ & & $\begin{array}{l}\text { Adhesion, Invasion, Biofilm production, Prolifer- } \\
\text { ation in Macrophages, Escape from Phagocy- } \\
\text { tosis, Inflammation activation and prevention of } \\
\text { IL-1b production }\end{array}$ \\
\hline
\end{tabular}




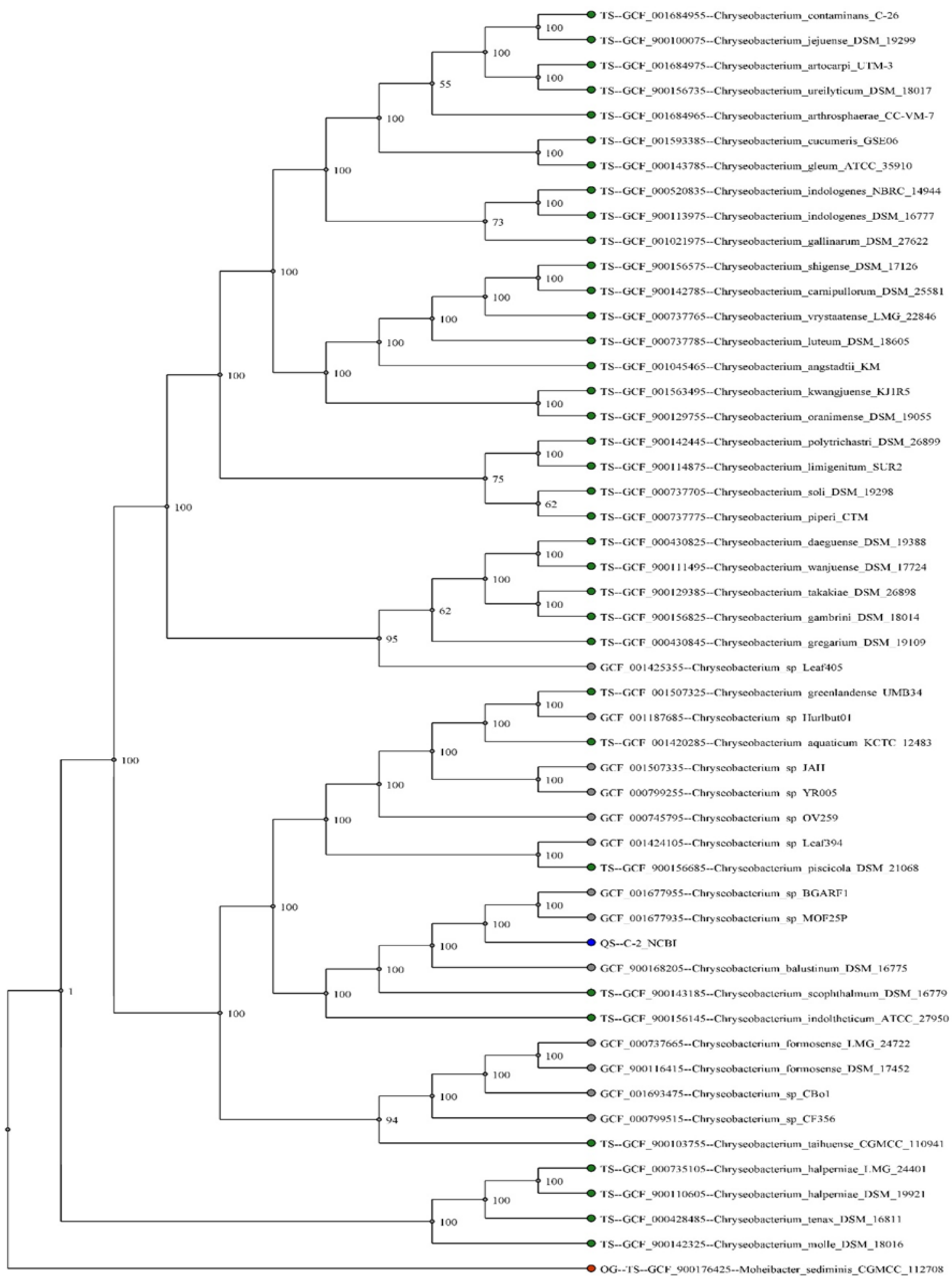

Figure 1. Phylogenetic tree of C-204 isolate (blue font) inferred from its draft genome using the software autoMLST. The phylogeny is rooted in Moheibacter sedimnis CGMCC 112708 (red), strains depicted in green font represent Chryseobacterium type strains 
204 genome after next-generation sequencing. The $C$ -204 genome was assembled after filtering with BBDuk and using the SPAdes algorithm. After assembling, 23 contigs and 4.012.452 bp long genome were obtained. The GC ratio of the C-204 draft genome was found to be $33.9 \%$. Genome characteristics of C-204 are presented in Table 2.

As a result of the autoMLST analysis performed with the closest 50 bacteria and 100 housekeeping gene regions, it was determined that the closest species to the C-204 isolate were C. greenlandense UMB34, Chryseobacterium sp. Hurlbut01 and C. aquaticum KCTC 12483 (Figure 1).

The draft genome of C-204 was registered with JABSUA000000000 accession number in GenBank. Eight antimicrobial resistance genes (AMR) and 13 virulence genes were detected in the genome of the C-204 isolate, and the related genes are presented in Table 3.

\section{Discussion and Conclusion}

While Chryseobacterium species do not cause any infection in domestic animals, it has been reported to cause infections in fish and frogs. The pathogenicity of $C$. aahli, C. piscicola, and C. balustinum in fish has been confirmed by experimental infection. Still, the pathogenicity of species such as $C$. chaponense, $C$. piscum, and $C$. arothri, which have been reported from systemic infections in fish in recent years, has not yet been confirmed. It has also been reported that some species within this genus, such as $C$. indologenes, are species with zoonotic potential that can cause diseases such as meningitis, urinary tract infections, and cystic fibrosis in humans (Hugo et al., 2019; Loch and Faisal, 2015a). At the same time, there is no study on the pathogenicity of $C$. aquaticum and C. greenlandense species in humans and fish.

In our study, detailed phenotypic characteristics of the C-204 isolate were determined by 106 different phenotypic tests (Biolog GEN III and API 20NE). It was seen that 19 of 66 tests were different from $C$. aquaticum type strain and 3 of 24 tests were different from C. greenlandense type strain. Also, 35 different tests that were not done before on these two types of strains were applied to the C-204 isolate for the first time. In shared biochemical tests (19 tests), C-204 isolate is differentiated from other type strains by nitrate reduction and production of acid from glucose. C-204 isolate, which was pre-identified as Chryseobacterium $\mathrm{sp}$. by conventional tests, was found to be $99.65 \%$ similar to C. aquaticum and $98.95 \%$ C. greenlandense by $16 \mathrm{~S}$ rRNA sequence analysis.

C. aquaticum was firstly isolated from healthy Siberian sturgeon juveniles in France, but the researchers reported the etiologic agent as Chryseobacterium sp.
(Bernardet et al., 2005). It was later isolated from a water reservoir in Korea, and the species description was made (Kim et al., 2008). Also, this pathogen was reported from the rainbow trout in Iran with ulcerative erosion in the tail fin and peduncle area (Akhlaghi et al., 2012). Loch et al. (2013) isolated C. aquaticum from brown trout juveniles with endophthalmitis, discoloration, fin erosion, and kidney swelling. An experimental infection has not yet demonstrated the pathogenicity of this agent in studies.

C. greenlandense was isolated from ice obtained from 3.043 meters deep of the ice sheet in Greenland (Loveland-Curtze et al., 2010). In our study, according to the phylogenetic analysis performed with autoMLST, it was determined that the C-204 isolate was in the same genogroup as the $C$. greenlandense UMB34 and C. aquaticum KCTC 12483 strains. In Bergey's Manuel of Systematics of Archaea and Bacteri, it was suggested that $C$. greenlandense and $C$. aquaticum belong to the same species due to the high genome similarity and to be named $C$. aquaticum, which was first published (Hugo et al., 2019). Besides, García-López et al., (2019) reported that $C$. greenlandense is not a different species, it is a subspecies of $C$. aquaticum, and its naming should be made as "Chryseobacterium aquaticum subsp greenlandense" in the taxonomic classification created with the type strains in the Bacteroidetes phylum.

C-204 was isolated from the kidney of 1 gram rainbow trout with symptoms such as a dorsal lesion, loss of appetite, abnormal swimming, discoloration, and exophthalmos in a trout farm in the Aegean region. Since there is no scientific study on the pathogenesis of the determined Chrysobacterium species, the virulence genes in the genome of the C-204 isolatewere analyzed in detail. Thirteen different putative virulence genes encoding adhesion, invasion, biofilm production, macrophage reproduction, escape from phagocytosis, inflammation inactivation, and blocking of IL-1b production were found in the C-204 isolate genome (Liu et al., 2019). It is recommended to conduct experimental infection studies in rainbow trout to show whether the agent provides pathogenesis and Koch Postulate.

Antimicrobial drugs including florfenicol, oxytetracycline, amoxicillin, enrofloxacin and sulfadiazine/ trimethoprim have been licensed by the Ministry of Agriculture and Forestry to treat fish diseases in Turkey. The most commonly used antimicrobials in aquaculture are florfenicol, oxytetracycline, and sulfadiazine/trimethoprim. There are a lot of studies that have been reported on the development of antimicrobial resistance in bacteria isolated from aquaculture (Balta et al., 2010; Duman et al., 2017; Durmaz et al., 2012; Onuk et al., 2017; Saticioglu et al., 2019). There is no antimicrobial susceptibility determination and interpretation model for Chryseobacterium spe- 
cies in EUCAST and CLSI standards. In this context, the antimicrobial susceptibility test protocol has been adapted according to previous studies on Chryseobacterium species. It has been reported that many agents in the Flavobacteriaceae family isolated from fish and clinical cases in humans can grow even at high concentrations of antimicrobials (Michel et al., 2005; Verner-Jeffreys et al., 2017). C. indologenes and $C$. gleum species isolated from clinical cases in humans have been naturally resistant to polymyxins, aminoglycosides (gentamicin, streptomycin, kanamycin), chloramphenicol, and most $\beta$-lactams (penicillins, cephalosporins, carbapenems) (Bellais et al., 2002; Lin et al., 2010). It has been reported that C. scophthalmum strains isolated in fish cases are resistant to tetracycline, aminoglycoside, lincomycin, oleandomycin, penicillin, and sulfadiazine in vitro, but are sensitive to chloramphenicol, sulfamethoxazoletrimethoprim, fusidic acid, and novobiocin (Mudarris and Austin, 1989). In our study, it was observed that C-204 isolate could grow even at high concentrations of Florfenicol, Oxytetracycline, Amoxicillin, and Sulphadiazine/Trimethoprim, which are licensed for fish. In the genome analysis, eight different antimicrobial resistance genes responsible for resistance against 15 different antibiotic classes were found. We concluded that the expression amount of the resistance genes detected in the genome of the C-204 isolate changes the phenotypic characteristic and makes the isolate resistant to antimicrobials.

This study is the first comprehensive study on $C$. aquaticum subsp greenlandense isolated from disease cases in rainbow trout. The phenotypic characteristics of the agent were determined for the first time using 106 different tests.

It has been determined that the C-204 isolate can grow even at high concentrations of antimicrobials commonly used in aquaculture and carry resistance genes against these antimicrobials in the genome.

It has been determined that there are 13 different virulence genes in the genome of the C-204 isolate, and these virulence genes may be responsible for the development of disease in rainbow trout.

Acknowledgments: This research was supported by The Research Fund of Erciyes University. Project Number: THD-2019-9135.

\section{References}

Akhlaghi M, Sharifiyazdi $\mathrm{H}$, Fereidouni MS. Isolation and identification of Chryseobacterium aquaticum from caudal fin rot and peduncle erosion in rainbow trout (Oncorhynchus mykiss). Iran J Vet Clin Sci 2012; 6: 19-27.

Alanjary M, Steinke K, Ziemert N. AutoMLST: an automated web server for generating multi-locus species trees highlighting natural product potential. Nucleic Acids Res 2019; 47(W1): W276-82.

Balta F, Sandalli C, Kayis S., Ozgumus OB. Molecular analysis of antimicrobial resistance in Yersinia ruckeri strains isolated from rainbow trout (Oncorhynchus mykiss) grown in commercial fish farms in Turkey. Bull Eur Ass Fish Pathol 2010; 30 (6): 211-9.

Bankevich A, Nurk S, Antipov D, Gurevich AA Dvorkin M, Kulikov AS, Lesin VM, Nikolenko SI, Pham S, Prjibelski AD, Pyshkin AV. SPAdes: A new genome assembly algorithm and its applications to single-cell sequencing. J Comput Biol 2012; 19(5): 455-77.

Bellais S, Naas T, Nordmann P. Genetic and biochemical characterization of CGB-1, an Ambler class $B$ carbapenem-hydrolyzing $\beta$-lactamase from Chryseobacterium gleum. Antimicrob Agents Chemother 2002; 46(9): 2791-6.

Bernardet JF, Vancanneyt M, Matte-Tailliez O, Grisez L, Tailliez P, Bizet C, Nowakowski M, Kerouault B, Swings J. Polyphasic study of Chryseobacterium strains isolated from diseased aquatic animals. Syst Appl Microbiol 2005; 28(7): 640-60.

BSGM. Su Ürünleri İstatistikleri. https:// www.tarimorman.gov.tr/sgb/Belgeler/ SagMenuVeriler/BSGM.pdf; Accessed Date: 22.09.2020

CLSI. Methods for Broth Dilution Susceptibility Testing of Bacteria Isolated from Aquatic Animals, Approved Guideline 2014a; VET04-A2: 1-20.

CLSI. Performance Standards for Antimicrobial Susceptibility Testing of Bacteria Isolated from Aquatic Animals; Second Informational Supplement 2014b; VET03/04-S2: 1-25.

Cooper A, Lambert D, Koziol AG, Seyer K, Carrillo CD. Draft genome sequence of Salmonella enterica subsp. enterica serovar mishmarhaemek isolated from bovine feces. Genome Announc 2015; 3(5): e01210-5.

Duman M, Saticioglu IB, Buyukekiz AG, Balta F, Altun S. Molecular characterization and antimicrobial resistance profile of atypical Citrobacter gillenii and Citrobacter sp. isolated from diseased rainbow trout (Oncorhynchus mykiss). J Glob Antimicrob Resist 2017; 10: 136-42.

Durmaz $Y$, Onuk EE, Ciftci A. Investigation of the presence and antibiotic susceptibilities of Flavobacterium psychrophilum in rainbow trout farms (Oncorhynchus mykiss Walbaum, 1792) in The Middle and Eastern Black Sea Regions of Turkey. 
Ankara Üniv Vet Fak Derg 2012; 59: 141-6.

Feldgarden M, Brover V, Haft DH, Prasad AB, Slotta DJ, Tolstoy I, Tyson GH, Zhao S, Hsu CH, McDermott PF, Tadesse DA. Validating the AMRFinder tool and resistance gene database by using antimicrobial resistance genotype-phenotype correlations in a collection of isolates. Antimicrob Agents Chemother 2019; 63(11): e00483-19.

García-López M, Meier-Kolthoff JP, Tindall B, Gronow S, Woyke T, Kyrpides NC, Hahnke RL, Göker M. Analysis of 1,000 type-strain genomes improves taxonomic classification of Bacteroidetes. Front Microbiol 2019; 10: 2083.

Hugo C, Bernardet JF, Nicholson A, Kämpfer P. Chryseobacterium . In Bergey's Manual of Systematics of Archaea and Bacteria (eds ME. Trujillo, S. Dedysh, P. DeVos, B. Hedlund, P. Kämpfer, F.A. Rainey and W.B. Whitman) 2019; p. 1-110

llardi P, Fernandez J, Avendano-Herrera R. Chryseobacterium piscicola sp. nov., isolated from diseased salmonid fish. Int J Syst Evol Microbiol 2009; 59(12): 3001-5.

Kearse $M$, Moir R, Wilson A, Stones-Havas $S$, Cheung M, Sturrock S, Buxton S, Cooper A, Markowitz S, Duran C, Thierer T. Geneious Basic: an integrated and extendable desktop software platform for the organization and analysis of sequence data. Bioinformatics 2012; 28(12): 1647-9.

Kim KK, Lee KC, Oh HM, Lee JS. Chryseobacterium aquaticum sp. nov., isolated from a water reservoir. Int J Syst Evol Microbiol 2008; 58(3): 533-7.

Lee YH, Tung KC, Cheng JF, Wu ZY, Chen SY, Hong YK, Huang YT, Liu PY. Genomic characterization of carbapenem-resistant Shewanella algae isolated from Asian hard clam (Meretrix lusoria). Aquaculture 2019; 500: 300-4.

Lin YT, Jeng YY, Lin ML, Yu KW, Wang FD, Liu CY. Clinical and microbiological characteristics of Chryseobacterium indologenes bacteremia. J Microbiol Immunol Infect 2010; 43(6): 498-505.

Liu B, Zheng D, Jin Q, Chen L, Yang J. VFDB 2019: a comparative pathogenomic platform with an interactive web interface. Nucleic Acids Res 2019; 47(D1): D687-92.

Loch TP, Faisal M. Emerging flavobacterial infections in fish: a review. J Adv Res 2015a; 6(3): 283-300.

Loch TP, Faisal M. Polyphasic characterization reveals the presence of novel fish-associated Chryseobacterium spp. in the Great Lakes of North America. Dis Aquat Org 2015b; 113(2): 113-25.
Loch TP, Faisal M. Chryseobacterium aahli sp. nov. isolated from lake trout (Salvelinus namaycush) and brown trout (Salmo trutta), and emended descriptions of Chryseobacterium ginsenosidimutans and Chryseobacterium gregarium. Int J Syst Evol Microbiol 2014; 64(5): 1573-9.

Loch TP, Fujimoto M, Woodiga SA, Walker ED, Marsh TL, Faisal M. Diversity of fish-associated flavobacteria of Michigan. J Aquat Anim Health 2013; 25(3): 149-64.

Loveland-Curtze J, Miteva V, Brenchley J. Novel ultramicrobacterial isolates from a deep Greenland ice core represent a proposed new species, Chryseobacterium greenlandense sp. nov. Extremophiles 2010; 14(1): 61-9.

Michel C, Matte-Tailliez O, Kerouault B, Bernardet JF. Resistance pattern and assessment of phenicol agents' minimum inhibitory concentration in multiple drug resistant Chryseobacterium isolates from fish and aquatic habitats. J Appl Microbiol 2005; 99(2): 323-32.

Mudarris M, Austin B. Systemic disease in turbot Scophthalmus maximus caused by a previously unrecognised Cytophaga-like bacterium. Dis Aquat Org 1989; 6(3): 161-6.

Onuk EE, Tanriverdi ÇY, Çoban AY, Ciftci A, Balta F, Didinen $\mathrm{BI}$, Altun S. Determination of antimicrobial susceptibility patterns of fish and rearing water originated Aeromonas isolates. Ankara Üniv Vet Fak Derg 2017; 64(1): 69-73.

Saticioglu IB, Duman M, Smith P, Wiklund T, Altun S Antimicrobial resistance and resistance genes in Flavobacterium psychrophilum isolates from Turkey. Aquaculture 2019; 512: 734293.

Tatusova T, DiCuccio M, Badretdin A, Chetvernin V, Nawrocki EP, Zaslavsky L, Lomsadze A, Pruitt KD, Borodovsky M, Ostell J. NCBI prokaryotic genome annotation pipeline. Nucleic Acids Res 2016; 144 (14): 6614-24.

Verner-Jeffreys DW, Brazier T, Perez RY, Ryder D, Card RM, Welch TJ, Hoare R, Ngo T, McLaren N, Ellis $\mathrm{R}$, Bartie $\mathrm{KL}$. Detection of the florfenicol resistance gene floR in Chryseobacterium isolates from rainbow trout. Exception to the general rule? FEMS Microbiol Ecol 2017; 93(4): fix015. 
